\title{
Effects of citrus rootstocks on fruit yield and quality of Ruby Red and Marsh grapefruit
}

\author{
Ali-Akbar RAMin ${ }^{a *}$, Ali ALIREZANEZHAD ${ }^{b}$
}

\author{
a Department of Horticulture, \\ College of Agriculture, Isfahan \\ University of Technology, \\ Isfahan 84156, Iran \\ aa-ramin@cc.iut.ac.ir \\ b Shahid Chamran University, \\ Ahwaz, Iran
}

${ }^{*}$ Correspondence and reprints

Received 21 March 2005

Accepted 15 August 2005

Fruits, 2005, vol. 60, p. 311-317 (C) 2005 Cirad/EDP Sciences All rights reserved DOI: 10.1051/fruits:2005037

RESUMEN ESPAÑOL, p. 317

\section{Effects of citrus rootstocks on fruit yield and quality of Ruby Red and Marsh grapefruits.}

Abstract - Introduction. Generally, in Iran, citrus cultivars are grafted on Sour orange rootstocks. However, susceptibility of this rootstock to tristeza (CTV) has required a research program to replace Sour orange trees with other rootstocks. Materials and methods. Yield performance and fruit quality of Ruby Red and Marsh grapefruits were assessed for 5 years (1999 to 2003) in the Agricultural Research Station in Dezful (Southern Iran) according to the eight different rootstocks used: Carrizo citrange, Citrus amblycarpa, Cleopatra mandarin, King mandarin, Sour orange, Swingle citrumelo, Troyer citrange and Volkamer lemon. Results and discussion. For the 5 years studied, cumulative yields per tree and yield per trunk cross-section area were the highest on Cleopatra mandarin, Sour orange, Swingle citrumelo and Volkamer lemon, whereas trees on Citrus amblycarpa, Carrizo citrange, King mandarin and Troyer citrange were the least productive. The results showed that individual fruit weight, size and skin thickness were significantly higher for both cultivars on Volkamer lemon, compared with the other rootstocks. Fruits on the Cleopatra mandarin rootstock had the lowest weight and fruit diameter. The rootstock type also affected the fruit juice amount and soluble solid content. Fruits from cultivars which were grafted on Sour orange rootstock had total soluble solids of $9.93 \%$ and $51 \%$ of juice content, whereas on Volkamer lemon rootstock, they had $7.81 \%$ of total soluble solids and $45.3 \%$ of juice content. Total acid of the fruits from cultivars grafted on Volkamer lemon had the significantly smallest amount (1.33\%). In both cultivars of grapefruits, no significant differences were observed except in the size of the fruit, fruit juice and vitamin $\mathrm{C}$ contents. Interactions between rootstock and cultivar were significantly different. Conclusion. Our results indicated that the yield and fruit quality of grapefruit are strongly influenced by the rootstock used. Also, the interaction between cultivars and rootstocks may be an interesting strategy for the adaptation of cultivars to different climatic areas. Iran Islamic Republic / Citrus paradisi / rootstocks / fruits / quality / yields

Effets de porte-greffes d'agrumes sur le rendement et sur la qualité des fruits des pomelos Ruby Red et Marsh.

Résumé - Introduction. Généralement, en Iran, les cultivars d'agrumes sont greffés sur des orangers amers. Cependant, la sensibilité de ce porte-greffe à la tristeza (CTV) a motivé le lancement d'un programme de recherche destiné à remplacer l'oranger amer par d'autres porte-greffes. Matériel et méthodes. Le rendement et la qualité des fruits des pomelos Ruby Red et Marsh ont été évalués pendant 5 années (1999 à 2003) dans le centre de recherches agricoles de Dezful (Iran méridional) à partir de l'utilisation de huit porte-greffes différents : citrange Carrizo, Citrus amblycarpa, mandarinier Cleopatra, mandarinier King, oranger amer, citrumelo Swingle, citrange Troyer et Citrus volkameriana. Résultats et discussion. Pendant les 5 années d'étude, les rendements cumulés par arbre et ceux rapportés à l'épaisseur du tronc ont été les plus élevés lors du greffage des pomelos sur mandarinier Cleopatra, oranger amère, citrumelo Swingle et Citrus volkameriana, alors que les cultivars greffés sur Citrus amblycarpa, citrange Carrizo, mandarinier King et citrange Troyer ont été les moins productifs. Les résultats ont montré que le poids du fruit, ainsi que la taille et l'épaisseur de la peau des fruits des deux cultivars de pomelo étaient sensiblement plus élevés sur les arbres greffés sur Citrus volkameriana que sur ceux greffés sur les autres porte-greffes. Les fruits sur mandarinier Cleopatra ont eu les poids et les diamètres de fruits les plus bas. En outre, le type de porte-greffe a affecté la quantité de jus de fruit et la teneur en solide soluble. Les fruits des cultivars greffés sur oranger amer ont eu des taux de solides solubles totaux de $9,93 \%$ et une teneur en jus de $51 \%$, tandis que, sur le porte-greffe Citrus volkameriana, ils ont eu 7,81\% de solides solubles totaux et $45,3 \%$ de jus. L'acidité totale des fruits des cultivars greffés sur Citrus volkameriana a eu les valeurs les plus faibles $(1,33 \%)$. Pour les deux cultivars de pomelo, aucune différence significative n’a été observée, exceptés la taille du fruit, la teneur en jus du fruit et son contenu en vitamine C. Les interactions entre portegreffe et cultivar ont été significativement différentes. Conclusion. Nos résultats indiquent que la production et la qualité des fruits du pomelo sont fortement influencés par le porte-greffe utilisé. En outre, l'interaction entre les cultivars et les porte-greffes pourrait être intéressante à considérer pour l'adaptation des cultivars aux différentes zones climatiques.

Iran République islamique / Citrus paradisi / porte-greffe / fruits / qualité / rendement 


\section{Introduction}

Citrus is the most important tree fruit crop in the world and grapefruit is an especially good fruit for the diet. Most citrus orchards worldwide consist of two-part trees that combine favorable attributes of the scion and rootstock. Rootstock selection is a major consideration in every citrus-growing operation. It should be carefully considered because such decisions are relatively permanent in their effect and thus in their longterm significance [1-3]. More than 20 horticultural characteristics are influenced by the rootstock including tree size, adaptation to certain soil conditions, fruit yield, size, texture, internal quality and maturity [3-5].

In southern Iran (Khozestan) most citrus cultivars are grafted on Sour orange rootstock. However, susceptibility of this rootstock to tristeza (CTV) in some cases has required a research program to replace Sour orange with other rootstocks for almost all the commercial cultivars including grapefruit. Economides and Gregoriou [6] reported that, over a 9-year production period in Cyprus, trees of Marsh grapefruit on Rough lemon and Citrus volkameriana were more productive per unit tree size and their cumulative yields per tree were significantly higher than those of trees on Sour orange. Georgiou [7] evaluated 12 rootstocks including Sour orange for Clementine mandarin in Cyprus. He reported that cumulative yield over 11 years was highest on Rough lemon followed by Volkamer lemon. Also, he concluded that the rootstock affected the fruit size and weight of individual fruit, rind thickness, juice content, brix and [brix/acid] ratio. There is evidence that the rootstock could affect the incidence of rind breakdown in sweet orange [5]. Earlier, Castle and Phillips [8] had studied the effect of 18 rootstocks on the performance of Marsh grapefruit in a closely spaced planting. They proposed that the rootstock had significant effects on tree size, yield, fruit quality and the quantity of soluble solid per tree. They recommended Rough lemon and Swingle trifoliate orange as the best rootstocks for these purposes. There are several reports that indicated a rootstock effect on the quality of fruit, yield and tree growth and tree size [9-11]. The rootstock can also affect growth and fruit quality, leaf mineral composition and, to some degree, tolerance to environmental stress [12].

External quality may be less important than yield if the fruit is for processing, and this would affect the choice of rootstock. However, if the fruit is for the fresh market, the influence of the rootstock on external quality may become more important. Therefore, in our study, scion-rootstock relationships were considered, with respect to their fruit yield and quality attribute for two grapefruit types, Ruby Red and Marsh.

\section{Materials and methods}

Our experiment was carried out during the years 1999 to 2003, with 7-year-old trees of grapefruit (Citrus paradisi Macf.) cvs. Ruby Red and Marsh, located in Dezful, Safiabad province, southwest Iran (lat. $32^{\circ} 20^{\prime} \mathrm{N}$, long. $48^{\circ} 24^{\prime} \mathrm{E}$, alt. $143 \mathrm{~m}$ ). The rootstocks were Sour orange (C. aurantium L.), Cleopatra mandarin (C. reticulata Blanco), Troyer citrange [Poncirus trifoliata $\times C$. sinensis, (L.) Osb.], Carrizo citrange [C. sinensis (L.) Osb. $\times$ P. trifoliata (L.) Raf.], Swingle citrumelo [C. paradise Macp. $\times$ P. trifoliata (L.) Raf.], Volkamer lemon (C. volkameriana Pasq.), Citrus amblycarpa (C. limonellus var. amblycarpa Hassk.) and King mandarin (C. loureiro). The orchard was planted in 1995 using three replications of four tree plots and a randomized complete-block design. The tree raw spacing was $6.5 \mathrm{~m} \times$ $4.2 \mathrm{~m}$. The soil was silty clay loam with $\mathrm{pH}$ of 8 and an electrical conductivity of $0.8-$ $1 \mathrm{dS} / \mathrm{m}$ of the saturation extract throughout the profile. Orchard care was similar to commercial practices in the area. Dam water was used for irrigation and the trees were irrigated with furrows. The area has an average yearly rainfall of $350 \mathrm{~mm}$, occurring mainly from November to April. Mean maximum air temperature is $45^{\circ} \mathrm{C}$ in July, with a mean minimum of $5.8{ }^{\circ} \mathrm{C}$ in February. Relative humidity ranges from $60-80 \%$ during the winter months and from $60-75 \%$ in the summer. Trees were fertilized twice a year, in early spring and summer with $\mathrm{N}, \mathrm{P}$ and $\mathrm{K}$ and the amount increased progressively each year to reach $120 \mathrm{~kg} \mathrm{~N} \cdot \mathrm{ha}^{-1}$ as ammonium sulphate, $90 \mathrm{~kg} \mathrm{P} \cdot \mathrm{ha}^{-1}$ as ammonium 
phosphate and $60 \mathrm{~kg} \mathrm{~K} \cdot \mathrm{ha}^{-1}$ as potassium sulphate.

Fruits were harvested and yields per tree measured during the years 1999 to 2003 at the beginning of each year (January) when the crop was fully matured. Tree size was measured in January each year and relative tree size was expressed in $\mathrm{cm}^{2}$ of the trunk cross-section area at a fixed point $15 \mathrm{~cm}$ above the bud union. Twenty fruits per tree were randomly collected and analyzed for quality. Fruits were weighed and fruit diameter (at the equator) and rind thickness were measured. Juice was extracted with an electric juice extractor and the juice from individual fruit was pooled, filtered through cheesecloth and used for chemical analysis. Total soluble solids were calculated from refractive indexes using a hand refractometer requiring a drop of undiluted juice (Model K-0032, Cosmo, Japan). Titrable acidity was calculated from the titrated volume of standard $0.1 \mathrm{~N} \mathrm{NaOH}$ to $\mathrm{pH} 8.2$ and expressed in $\mathrm{mg}$ of citric acid $100 \mathrm{~mL}^{-1}$ of juice [13]. Vitamin $C$ also was measured with titration of juice with chlorophenol indophenol and presented as $\mathrm{mg} \cdot 100 \mathrm{~mL}^{-1}$ of juice [13]. All chemical analyses were run in duplicate on the same samples. Data were analyzed using a statistical computing system; the analysis of variance procedure was used and leastsquare means were tested using least square difference (LSD) at the $p<0.05$ level.

\section{Results}

\subsection{Fruit yield}

Cumulative yields showed that, compared with the other rootstocks, Volkamer lemon produced significantly $(p<0.05)$ more fruit when grafted with both cultivars, followed by trees on Cleopatra and Swingle citrumelo (table I). In fact, trees on Volkamer lemon, Cleopatra and Swingle citrumelo produced $(37,13.4$ and 6.5$) \%$ more fruits than on Sour orange, respectively. Trees on Citrus amblycarpa, King mandarin, Carrizo citrange, Troyer citrange and Sour orange produced the lowest yields.

In both cultivars, the largest trees (trunk cross-section area) were on Troyer citrange,
Carrizo citrange and Citrus amblycarpa $(p<$ $0.05)$; the smallest ones were on Cleopatra and Sour orange (table I).

In order to indicate the effectiveness of the rootstock on productivity of trees in relation to tree size, the yield per trunk crosssection area was calculated. Productivity of both cultivars based on the [fruit/trunk] cross-section areas was similar for all the rootstocks. Generally, grapefruits grafted on Volkamer lemon and Cleopatra were more productive than those on the other rootstocks, whereas those on King mandarin were the least productive. Therefore, from our present results, there was no relationship between average tree size and cumulative yield per tree.

\subsection{Fruit quality}

Regardless of the rootstock, there was significant difference $(p<0.05)$ in some fruit quality parameters between the Marsh and Ruby Red grapefruits examined in our study (table II): fruit diameter, percentage of fruit juice content and vitamin $\mathrm{C}$ content of fruit were significantly higher in Marsh fruits than in Ruby Red ones. However, there was no significant change in other fruit parameters in both cultivars.

Rootstocks affected fruit weight, size and rind thickness of the fruits. Individual fruit weight ranged from $353 \mathrm{~g}$ on Cleopatra mandarin to $389 \mathrm{~g}$ on Volkamer lemon, the highest fruit weight, which was significantly different $(p<0.05)$ from that of fruits on the other rootstocks. Fruit diameter and rind thickness were also higher in fruits from Volkamer lemon than in the other rootstocks. Trees on Cleopatra mandarin, Citrus amblycarpa, King mandarin, Citrumelo, Carrizo citrange and Troyer citrange produced fruit with similar juice content. However, Sour orange significantly increased the juice percent (51\%) and Volkamer lemon significantly decreased it (45\%). Trees on all the rootstocks produced fruits with similar total soluble solids and titrable acidity except fruits from Volkamer lemon rootstock, for which total soluble solids significantly decreased $(p<0.05)$. There was no significant difference in the [total soluble solids / titrable acidity] ratio in fruits from all rootstocks. 
Table I.

Effect of rootstock on yield and trunk cross-sectional area of Marsh and Ruby Red grapefruits (Iran).

\begin{tabular}{|c|c|c|c|c|c|c|c|c|}
\hline \multirow[t]{2}{*}{ Citrus name } & \multicolumn{5}{|c|}{$\begin{array}{l}\text { Average annual yield per tree } \\
(\mathrm{kg})\end{array}$} & \multirow{2}{*}{$\begin{array}{l}\text { Cumulative yield } \\
\text { per tree } \\
(\mathrm{kg})\end{array}$} & \multirow{2}{*}{$\begin{array}{l}\text { Trunk cross-section } \\
\text { area }{ }^{1}(2003) \\
\left(\mathrm{cm}^{2}\right)\end{array}$} & \multirow{2}{*}{$\begin{array}{l}\text { Cumulative yield } \\
\text { per trunk cross- } \\
\text { section area } \\
\left(\mathrm{kg} \cdot \mathrm{cm}^{-2}\right)\end{array}$} \\
\hline & 1999 & 2000 & 2001 & 2002 & 2003 & & & \\
\hline \multicolumn{9}{|l|}{ Marsh grapefruit } \\
\hline Carrizo citrange & 140 & 145 & 130 & 140 & 194 & 749 & 122 & 6.1 \\
\hline Citrus amblycarpa & 135 & 95 & 175 & 150 & 200 & 755 & 121 & 6.2 \\
\hline Cleopatra mandarin & 140 & 105 & 210 & 190 & 270 & 915 & 107 & 8.5 \\
\hline King mandarin & 106 & 85 & 130 & 110 & 180 & 611 & 119 & 5.1 \\
\hline Sour orange & 143 & 141 & 170 & 155 & 205 & 818 & 114 & 7.1 \\
\hline Swingle citrumelo & 127 & 130 & 190 & 200 & 243 & 890 & 120 & 7.4 \\
\hline Troyer citrange & 110 & 126 & 165 & 160 & 194 & 750 & 125 & 6.0 \\
\hline Volkamer lemon & 170 & 150 & 260 & 230 & 290 & 1100 & 117 & 9.4 \\
\hline \multicolumn{9}{|l|}{ Ruby Red grapefruit } \\
\hline Carrizo citrange & 138 & 130 & 127 & 158 & 19 & 745 & 124 & 6.0 \\
\hline Citrus amblycarpa & 136 & 96 & 173 & 148 & 210 & 763 & 125 & 6.1 \\
\hline Cleopatra mandarin & 138 & 101 & 201 & 189 & 266 & 895 & 109 & 8.2 \\
\hline King mandarin & 110 & 90 & 129 & 109 & 179 & 617 & 118 & 5.2 \\
\hline Sour orange & 140 & 121 & 163 & 153 & 201 & 779 & 112 & 6.9 \\
\hline Swingle citrumelo & 125 & 142 & 108 & 194 & 241 & 810 & 114 & 7.1 \\
\hline Troyer citrange & 108 & 128 & 160 & 159 & 14 & 739 & 125 & 5.9 \\
\hline Volkamer lemon & 164 & 146 & 261 & 226 & 300 & 1097 & 119 & 9.2 \\
\hline $\operatorname{LSD}(p<0.05)$ & 16.8 & 13.3 & 21.5 & 18.3 & 26.9 & 68 & 8.3 & 1.7 \\
\hline
\end{tabular}

Vitamin C of juice was also affected by the type of rootstock. Concentrations of vitamin $\mathrm{C}$ in fruits from Citrus amblycarpa, Volkamer lemon and Cleopatra mandarin, respectively, were higher than the other rootstocks considered here, but differences were not significant with fruits from Sour orange. When the significant interaction effect of [cultivar $\times$ rootstock] on quality of fruit was studied, quality differences were again observed according to the rootstocks used (table III). Good quality fruit in size and vitamin $\mathrm{C}$ of both types was produced from fruit grafted on Volkamer lemon, Citrus amblycarpa, Swingle citrumelo, Carrizo citrange and Troyer citrange compared with the use of Sour orange.

\section{Discussion}

In our study, Volkamer lemon was clearly the best rootstock; trees grafted on it were highly productive and with large fruits. During the 5-year harvest periods considered, fruit yield of trees grafted on Volkamer lemon was $34 \%$ higher than fruit yield obtained on Sour orange, the standard rootstock used in southwestern Iran; it was 20\% higher than yield on Cleopatra mandarin, which presented a fruit yield $12 \%$ higher than yield on Sour orange. Moreover, trees on Volkamer lemon were outstanding and exceeded all other rootstocks in respect of yield in relation to tree size. The least productive trees were those grafted on King mandarin, Troyer citrange, Carrizo citrange and Citrus amblycarpa. Most of our results are in agreement with those obtained for citrus elsewhere [6, 7, 11].

Citrus volkameriana (Volkamer lemon) is a hybrid which, as a rootstock, produced vigorous trees yielding large quantities [3]. Scions grafted on Volkamer lemon are more freeze-hardy than those grafted on other rootstocks and they are not susceptible to 
Table II.

Chemical composition and fruit quality characteristics of grapefruit grafted on different rootstocks (Iran). Each value is a mean of 5 years (1999 to 2003).

\begin{tabular}{|c|c|c|c|c|c|c|c|c|}
\hline Citrus name & $\begin{array}{l}\text { Fruit weight } \\
\text { (g) }\end{array}$ & $\begin{array}{l}\text { Fruit diameter } \\
\qquad(\mathrm{cm})\end{array}$ & $\begin{array}{l}\text { Rind thickness } \\
\qquad(\mathrm{mm})\end{array}$ & $\begin{array}{l}\text { Juice } \\
(\%)\end{array}$ & $\begin{array}{c}\text { Total soluble solid } \\
\text { (\%) }\end{array}$ & $\begin{array}{l}\text { Total acid [ } \\
(\%)\end{array}$ & $\begin{array}{c}\text { [Total soluble solid / } \\
\text { total acid] }\end{array}$ & $\begin{array}{l}\text { Vitamin C } \\
\mathrm{mg} \cdot 100 \mathrm{~mL}^{-}\end{array}$ \\
\hline \multicolumn{9}{|l|}{ Scion } \\
\hline Marsh grapefruit & 370.7 & 9.8 & 6.7 & 48.2 & 9.4 & 1.5 & 5.9 & 37.0 \\
\hline Ruby Red grapefruit & 369.9 & 9.6 & 6.5 & 48.7 & 9.4 & 1.5 & 6.0 & 35.0 \\
\hline $\operatorname{LSD}(p<0.05)$ & ns & 0.08 & ns & 0.3 & ns & ns & ns & 0.6 \\
\hline \multicolumn{9}{|l|}{ Rootstock } \\
\hline Carrizo citrange & 371.4 & 9.7 & 6.7 & 48.4 & 9.6 & 1.6 & 5.9 & 36.8 \\
\hline Citrus amblycarpa & 367.6 & 9.8 & 7.0 & 48.6 & 9.7 & 1.6 & 6.0 & 38.6 \\
\hline Cleopatra mandarin & 353.6 & 9.0 & 6.3 & 49.3 & 9.5 & 1.5 & 6.0 & 37.0 \\
\hline King mandarin & 364.3 & 9.8 & 6.3 & 48.3 & 9.5 & 1.6 & 5.7 & 34.4 \\
\hline Sour orange & 371.0 & 9.8 & 6.2 & 51.0 & 9.9 & 1.6 & 6.1 & 36.2 \\
\hline Swingle citrumelo & 372.4 & 9.6 & 6.4 & 48.8 & 9.8 & 1.5 & 6.2 & 34.7 \\
\hline Troyer citrange & 373.2 & 9.7 & 6.6 & 48.0 & 9.6 & 1.6 & 6.0 & 35.4 \\
\hline Volkamer lemon & 388.9 & 10.1 & 7.3 & 45.3 & 7.8 & 1.3 & 5.8 & 37.2 \\
\hline $\operatorname{LSD}(p<0.05)$ & 1.3 & 0.1 & 0.5 & 0.6 & 0.4 & 0.08 & ns & 1.2 \\
\hline
\end{tabular}

ns: not significant at the $5 \%$ level.

\section{Table III.}

[Cultivar $\times$ rootstock] effects on fruit quality characteristics of grapefruit (Iran). Each value is a mean of 5 years (1999 to 2003).

\begin{tabular}{|c|c|c|c|c|c|c|c|c|}
\hline Citrus name & $\begin{array}{l}\text { Fruit weight } \\
\qquad(\mathrm{g})\end{array}$ & $\begin{array}{l}\text { Fruit diameter } \\
(\mathrm{cm})\end{array}$ & $\begin{array}{l}r \text { Rind thickness } \\
\qquad(\mathrm{mm})\end{array}$ & $\begin{array}{l}\text { Juice } \\
(\%)\end{array}$ & $\begin{array}{c}\text { Total soluble solid } \\
(\%)\end{array}$ & $\begin{array}{l}\text { Total acid } \\
(\%)\end{array}$ & $\begin{array}{c}\text { [ Total soluble solid / } \\
\text { total acid] }\end{array}$ & $\begin{array}{l}\text { / Vitamin C } \\
\left(\mathrm{mg} \cdot 100 \mathrm{~mL}^{-1}\right)\end{array}$ \\
\hline \multicolumn{9}{|l|}{ Marsh grapefruit } \\
\hline Carrizo citrange & 365 & 9.8 & 6.8 & 47.9 & 9.5 & 1.6 & 5.6 & 35 \\
\hline Citrus amblycarpa & 364 & 9.8 & 6.0 & 48.0 & 9.2 & 1.5 & 6.2 & 35 \\
\hline Cleopatra mandarin & 355 & 9.3 & 6.1 & 48.5 & 9.1 & 1.5 & 6.0 & 40 \\
\hline King mandarin & 360 & 9.7 & 6.2 & 47.9 & 9.6 & 1.6 & 5.7 & 35 \\
\hline Sour orange & 374 & 9.8 & 6.2 & 50.0 & 9.8 & 1.5 & 5.7 & 39 \\
\hline Swingle citrumelo & 368 & 9.7 & 6.0 & 48.2 & 9.5 & 1.5 & 6.0 & 35 \\
\hline Troyer citrange & 374 & 9.8 & 6.8 & 47.8 & 9.1 & 1.6 & 5.6 & 36 \\
\hline Volkamer lemon & 390 & 10.2 & 7.2 & 45.0 & 7.6 & 1.3 & 6.0 & 39 \\
\hline \multicolumn{9}{|l|}{ Ruby red grapefruit } \\
\hline Carrizo citrange & 374 & 9.7 & 6.4 & 48.0 & 9.2 & 1.5 & 5.3 & 36 \\
\hline Citrus amblycarpa & 366 & 9.7 & 6.9 & 48.6 & 9.5 & 1.6 & 5.6 & 41 \\
\hline Cleopatra mandarin & 349 & 8.7 & 6.0 & 48.7 & 9.0 & 1.5 & 6.0 & 33 \\
\hline King mandarin & 364 & 9.6 & 6.0 & 48.1 & 9.0 & 1.6 & 5.5 & 32 \\
\hline Sour orange & 364 & 9.7 & 6.0 & 51.7 & 9.8 & 1.5 & 5.9 & 32 \\
\hline Swingle citrumelo & 374 & 9.5 & 6.0 & 48.8 & 9.8 & 1.5 & 6.0 & 34 \\
\hline Troyer citrange & 368 & 9.7 & 6.2 & 47.9 & 9.3 & 1.5 & 6.0 & 33 \\
\hline Volkamer lemon & 386 & 10.0 & 7.0 & 45.0 & 7.6 & 1.3 & 5.6 & 34 \\
\hline $\operatorname{LSD}(p<0.05)$ & 2.9 & 0.24 & 0.74 & 0.95 & 0.62 & 0.12 & 0.62 & 1.2 \\
\hline
\end{tabular}


the citrus tristeza virus (CTV), Xyloporosis, Malsecco or Phytophthora under most conditions [7, 14]. However, in most citrus orchards, Volkamer lemon is not widely used as a rootstock, but it has been extensively planted in recent years in areas which have lost Sour orange trees because of the CTV virus. Nevertheless, some studies from Florida [3] suggested that yields and net profits over the long term are higher for trees grafted on Volkamer lemon than for others grafted on less vigorous rootstocks such as Swingle citrumelo even when tree losses due to blight or other factors are moderate.

Although our data showed that fruit quality can be markedly influenced by rootstocks, the slightly lower acid, soluble solid content and percentage of juice content in the fruits of trees grafted on Volkamer lemon, compared with those in fruits of trees grafted on Sour orange and Cleopatra mandarin were significant, but the difference was slight [15]. The low soluble solid content and juice percentage of fruits of trees grafted on Volkamer lemon rootstock could be due to the large size and the high yields of these fruits [7]. However, our results also demonstrated the undesirability of making a rootstock decision using one factor alone; for example, the juice content and brix value of fruits from trees grafted on Volkamer lemon were comparatively low, but the quantity of soluble solid per tree and fruit size were high because of the large yield. Mechanisms of rootstock effect on fruit quality were discussed by Castle [16] using apple (a climacteric starch-accumulating fruit) and citrus (non-climacteric and accumulating soluble solid). He proposed that the quality in apples is largely related to crop load and to canopy management, whereas the quality of the citrus fruit juice is closely related to the rootstock effects due to the plant-water relation that regulated field trial results, sucrose transport and reciprocal fruit-grafting studies.

\section{Conclusion}

In general, there is no perfect rootstock even for a particular situation. Choice of rootstock should be based on the most important limiting factors. For example, if the limiting fac- tor is the presence of tristeza in the orchards, from the results that we obtained, it may be possible to replace rootstocks of commercial Sour orange with Volkamer lemon and Cleopatra mandarin rootstocks.

\section{Acknowledgements}

The authors wish to thank all the staff members of the Agricultural Experimental Research Station in Dezful (Iran) for running the experiment and providing the experimental materials.

\section{References}

[1] Castle W.S., Rootstock selection, Fla. Coop. Ext. Serv., Univ. Fla., HS-151, USA, 1992.

[2] Hartman H.T., Kester D.E., Davies Jr. F.T., Plant propagation: principle and practices, 5th ed., Prentices Hall Int., Englewood Cliffs N.J., USA, 1990.

[3] Davies F.S., Albrigo L.G., Citrus, CAB Int., UK, 1995.

[4] Daugaard H., Callesen O., The effect of rootstock on yield and quality of Mutsu apples, J. Hortic. Sci. Biotech. 77 (2002) 248-251.

[5] Agusti M., Almela V., Juan M., Mesejo C., Martinez-Fuentes A., Rootstock influence on the incidence of rind breakdown in Navelate sweet orange, J. Hortic. Sci. Biotech. 78 (2003) 554-558.

[6] Economides C.V., Gregoriou C., Growth, yield, and quality of nucellar Frost 'Marsh' grapefruit on fifteen rootstocks in Cyprus, J. Am. Soc. Hortic. Sci. 118 (3) (1993) 326-329.

[7] Georgiou A., Evaluation of rootstocks for Clementine mandarin in Cyprus, Sci. Hortic. 93 (2002) 29-38.

[8] Castle W.S., Phillips R.L., Performance of Marsh grapefruit and Valencia orange trees on eighteen rootstocks in a closely spaced planting, J. Am. Soc. Hortic. Sci. 105 (1980) 496-499.

[9] Economides C.V., Performance of Marsh seedless grapefruit on six rootstocks in Cyprus, J. Hortic. Sci. 51 (1976) 393-400.

[10] Economides C.V., The influence of rootstocks on tree growth, yield, and fruit quality of Valencia oranges in Cyprus, J. Hortic. Sci. 52 (1977) 29-36. 
[11] Wutscher H.K., Performance of Hamlin orange on 30 citrus rootstocks in southern Florida, J. Am. Soc. Hortic. Sci. 113 (1988) 493-497.

[12] Camara J.M., Garcia-Sanchez F., Nieves M., Cerda A., Effect of interstock ('Salustiano' orange) on growth, leaf mineral composition and water relations of one year old citrus under saline conditions, J. Hortic. Sci. Biotech. 78 (2) (2003) 161-167.

[13] Anon., Official methods of analysis, 13th ed., Association of Official Analysis Chemists (AOAC), Washington DC, USA, 1980.
[14] Carpenter J.B., Burns R.M., Sedlacek R.F., Phytophthora resistant rootstocks for Lisbon lemon in California, Citrograph 67 (1981) 287-292.

[15] Protopapadakis E., Voulgaropoulos A., Sofoniou M., Rootstocks affect leaf and fruit mineral concentrations of Washington navel orange, Fruits 53 (1998) 167-173.

[16] Castle W.S., Review: rootstock as a fruit quality factor in citrus and deciduous tree crops, New Zeal. J. Crop Hort. 23 (1995) 383-394.

\section{Efectos de patrón de cítricos sobre el rendimiento y sobre la calidad de las frutas de los pomelos Ruby Red y Marsh.}

Resumen - Introducción. Generalmente, en Irán, los cultivares de cítricos se injertan en los naranjos agrios. Sin embargo, la sensibilidad de este patrón de la tristeza (CTV) motivó la puesta en marcha de un programa de investigación destinado a sustituir el naranjo agrio por otros patrones. Material y métodos. El rendimiento y la calidad de las frutas de los pomelos Ruby Red y Marsh se evaluaron durante 5 años (1999 a 2003) en el centro de investigaciones agrícola de Dezful (Irán meridional) a partir de la utilización de ocho púa-patrones diferentes: el citranjo Carrizo, Citrus amblycarpa, el mandarinero Cleopatra, el mandarinero King, el naranjo agrio, el citrumelo Swingle, el citranjo Troyer y Citrus volkameriana. Resultados y discusión. Durante los 5 años de estudio, los rendimientos acumulados por árbol y aquellos relacionados con el grosor del tronco fueron los más elevados en el injerto de los pomelos en el mandarinero Cleopatra, el naranjo amargo, el citrumelo Swingle y el Citrus volkameriana, mientras que los cultivares injertados en el Citrus amblycarpa, el citranjo Carrizo, el mandarinero King y el citranjo Troyer fueron los menos productivos. Los resultados pusieron de manifiesto que el peso de la fruta, así como la talla y el grosor de la piel de las frutas de los dos cultivares de pomelo eran sensiblemente más elevados en los árboles injertados en el Citrus volkameriana que en aquellos injertados en los otros patrones. Los frutos sobre el mandarinero Cleopatra tuvieron el peso y el diámetro de frutos más bajos. Además el tipo de patrón afectó la cantidad de jugo de fruta así como el contenido de sólido soluble. Los frutos de los cultivares injertados en el naranjo amargo tuvieron porcentajes de sólidos solubles totales del 9,93\% y un contenido en jugo del 51\%, mientras que en el púa-patrón Citrus volkameriana, tuvieron un $7,81 \%$ de sólidos solubles totales y un $45,3 \%$ de jugo. La acidez total de las frutas de los cultivares injertados en el Citrus volkameriana tuvo los valores más bajos (1,33\%). En los dos cultivares de pomelo, no se observó ninguna diferencia significativa, salvo el tamaño de la fruta, el contenido en jugo de la fruta y su contenido en vitamina C. Las interacciones entre el patrón y el cultivar fueron significativamente diferentes. Conclusión. Nuestros resultados indican que la producción y la calidad de las frutas del pomelo están influenciadas por el patrón utilizado. Además la interacción entre los cultivares y los patrones podría ser interesante a considerar para la adaptación de los cultivares en las diferentes zonas climáticas.

\section{Iran República Islámica / Citrus paradisi / portainjerto / frutas / calidad /} rendimiento 